\title{
4 Monosexual church policies and plurisexual youth cultures
}

\author{
Carol A. Shepherd
}

\section{Introduction: A conspiracy of silence?}

YouGov (2015) revealed in a poll that 49 per cent of young people in the United Kingdom did not identify as 100 per cent heterosexual. In a more recent report, UK anti-bullying organisation Ditch the Label (2017) put the figure at 57 per cent, while the Williams Institute at UCLA (2018) showed an increased tolerance of LGBT people in its Global Acceptance Index. Given these statistics, why do clergy attitudes and church doctrines remain resolutely binary in the face of growing sexual and gender diversity among young people? This is the theoretical question at the heart of this chapter.

Over 30 years ago, Fritz Klein noted in his seminal work on bisexuality, The Bisexual Option (1978), that social institutions - including churches routinely ignored bisexuality in discourses on human sexuality. It seems that in the ensuing three decades, nothing has changed in the church, while both not-for-profit and commercial organisations clamour to compete for the LGBT currency as part of a growing acceptance of sexual minority rights. Indeed, the LGBT marketing consultancy Out Now (2015), in the biggest survey of its kind in 2015, has shown just why both American and European companies are so keen to attract LGBT employees from both a financial and customer loyalty standpoint. Given that both financial support and congregant retention are key considerations for most ecclesiastical organisations and I speak from my own experience of serving in church leadership - it is perhaps surprising that less attention is paid to the potential financial and sociocultural benefits of extending the table to welcome the full range of LGBT+ identities. Is it truly the case that those who would leave the organisation on principle, on acceptance of LGBT+ congregants, would outnumber those whom such a policy would attract into the church? And even if this were to be the case, what long-term ramifications would such a stance have for the future viability of the church, given that a substantial percentage of the current generation do not identify as exclusively straight?

Despite bisexual people comprising over half of all LGBT people, there appears to be little movement away from binary thinking in the new shift towards affirming discourse within certain Christian denominations. This 


\section{Carol A. Shepherd}

represents a colossal own goal on the part of the church, alienating the very youth it is so desperately trying to attract in its attempts to breathe new life into a dying institution. The UK Government's National LGBT Survey (2019) revealed that young people are the most likely to identify as bisexual. It is abundantly clear that neither gender identity nor sexual orientation is viewed as a binary concept in the minds of young people today, a state of play that perplexes church leaders seeking flawed simplicity over nuanced realities to retain existing doctrinal positions. As Yip (2003) notes in his study of the Roman Catholic Church, Christians are changing, but the church itself is not willing to follow suit.

In my previous research into bisexuality in the United Kingdom (Shepherd 2017, 2018), I discovered that only one Christian organisation in the whole of the United Kingdom - North London Metropolitan Community Church - offered a stand-alone pastoral leaflet on bisexuality, and only a handful had mentioned bisexuality within church services. Elsewhere, the orientation was ignored or subsumed within homosexuality. It is thus within this sobering context that I set about considering the situation for (vulnerable) young Christian people with plurisexual identities.

\section{Methods}

This chapter chiefly aims to explore some of the theoretical grounds for this apparent conspiracy of silence over bisexuality. To locate this chapter within a European context, I also exemplify the theoretical issues underpinning bisexual Christian erasure with some initial findings from my empirical research into bisexual Christians around Europe, which is being conducted on behalf of the European Forum of LGBT Christian Groups (Shepherd, in press). This project is currently at the data-collection stage and is thus not ready for full analysis. While it does not focus specifically on the 1824 years age group, the study does feature a significant proportion of college students within this age range.

\section{A survey of existing literature on the bisexual Christian intersection}

It would be fair to say that existing literature on the bisexual-Christian intersectional identity is sparse. Besides my own empirical studies of bisexual Christians in the United Kingdom and the United States (Shepherd, 2018), the only considerable body of work to coexist on this intersection is that of UK scholars Andrew Yip and Alex Toft (Toft, 2012, 2014; Yip, 2003; Yip and Toft, 2020)

Beyond Yip, Toft and myself, UK activist Jaime Sommers (2016) has published an autobiographical trade publication, 119: My Life as a Bisexual Christian. Elsewhere, Levy and Harr (2018), Robinson (2015), AlfordHarkey and Haffner (2014), Hutchins and Williams (2014), Lingwood 
(2010) and Kolodny (2000) have touched on the bisexual Christian intersection from a theoretical perspective within chapters in edited volumes or in stand-alone journal articles. Alford-Harkey and Haffner (2014) have written a general, non-academic church resource for those who pastor bisexual Christians in the United States. However, what the majority of such writings on the bisexual Christian experience have in common, as Toft (2012) notes, is that they largely focus on individuals who have moved out of faith communities, so offer little in the way of coping mechanisms and solutions for those who wish to negotiate a position and sense of embodied faith within church organisations.

Of the above authors, only Yip, Toft and myself have undertaken extensive empirical research with bisexual Christians, while my monograph, Bisexuality in the Western Christian Church: The Damage of Silence (Shepherd, 2018), based on my doctoral thesis (Shepherd, 2017), is the only work to encompass qualitative research with both church practitioners and their bisexual congregants, and my findings are also discussed in an edited volume by Yip and Toft (2020). Yet, while publishing output is slowly increasing on the bisexual-Christian intersection, it remains authored by a select band of scholars, and this is problematic in a climate where the monosexual discourses of the church are at odds with the plurisexual realities of secular society, as revealed in the social surveys featured in the introduction to this chapter.

This paucity of publishing output on the bisexual Christian intersection is perhaps symptomatic of both the reticence of bisexual Christians to speak out and the unwillingness of the monosexual majority to give voice to the bisexual Christian experience. Yet the voice of the insider is crucial, as Stephen Lingwood (2010) outlines in his important article, "Bi Christian Unitarian: A Theology of Transgression". Speaking as a queer theologian, Lingwood asserts that more "us" theology is required (bisexual theology written by bisexual people), rather than "them" theology (theology written about bisexual people by straight or gay theologians). The insider view is crucial, given the widespread ignorance of the specific issues faced by bisexual Christians among both clergy and lay people, and also among academics.

This silence on the bisexual Christian experience translates into a lack of support for bisexual Christians within faith communities, as explored by Alex Toft. Toft (2012) demonstrates how bisexual Christians more often than not cease to regularly attend church worship, owing to the lack of welcome afforded them, exclusionary pastoral practices, and ignorance of bisexual identities. Toft (2012) shows that in the vast majority of cases more than 80 per cent - it is not overt acts of aggression against bisexuals that make them reluctant to be part of worship communities, but the unspoken sense of feeling unwelcome. In other words, the silence on bisexuality as a valid subject for debate or valid identity for a Christian is what drives bisexual Christians away from organised religion. This is also the case within gay-affirming denominations, such as the Metropolitan Community 
Church, where gay and lesbian monosexist discourses dominate and serve to exclude plurisexual identities. Toft (2014) shows how this ignorance and wanton silence on the subject within churches leads bisexual people into concealing their sexuality and hiding behind the monosexual privilege that their opposite-sex, vis-à-vis same-sex, partner affords them, depending on whether the congregation is straight-affirming or lesbian-and-gay-affirming (but never bi-affirming).

My published body of work (Shepherd 2017,2018) concurs with Yip and Toft's findings, yet perhaps places more emphasis on the mental wellbeing fallout of this silence on the bisexual Christian intersection, with 88 per cent of the 54 bisexual Christian participants interviewed revealing depressive disorders of various degrees, from generalised anxiety disorders (GAD) to suicide ideation and attempts. While it would be disingenuous to lay the blame for poor mental wellbeing firmly at the door of binegative clergy and institutions - among this particular cohort, there were numerous parallel factors for adverse mental health - nor can the coexistence of a bisexual orientation and poor mental health be ignored.

\section{Theoretical background to bisexual erasure in the church}

As indicated above, this chapter seeks to establish the theoretical basis for the stigmatisation of bisexual Christians in the Christian church via themes that have emerged from existing empirical research and theories proposed by queer theologians and academics.

\section{Binary worship of the Holy Trinity}

As British theologian Adrian Thatcher (1993, p. 155) notes, "Bisexual people are almost always overlooked in discussions of sexuality". Is this silence concerning bisexuality deliberate or accidental?

In an academic article, Garrigan (2009, p. 155) poses the following question:

As you sing with the faithful in all times and all places, how often have you sung in terms that were not based on heterosexist binaries - father and mother, male and female? ... How is sexual diversity talked about and otherwise imaged in your worship? How do you recognise the one in every 2000 babies born with 'indeterminate' sex organs? How many prayers begin only, 'Brothers and Sisters?' How many of the worship leader's well-meaning remarks class people as 'gay or straight', as if they were the only options? How are bisexual people represented in your church, if at all? Are bisexual people mis-portrayed as 'straight' if they are in a male-female relationship?

That the church as a whole has made great progress in the acceptance of lesbian and gay individuals over the past ten years cannot be denied, 
the Roman Catholic and free evangelical church notwithstanding. In the 18 years since the Netherlands became the first country in Europe to legalise same-sex marriage, we find ourselves today in a situation where 16 out of 44 European countries allow same-sex marriage, albeit only within certain denominations (European Union, 2019). A larger number of European nations still allow LGBT clergy to be ordained, though those countries that oppose marriage equality tend to also impose celibacy on the incumbent priest. In the United Kingdom, same-sex couples may not legally marry in the established Church of England and LGBT clergy must abstain from homosexual acts (Church of England, 1991), though a "don't ask, don't tell" approach is widely practised within all but the most conservative dioceses.

It might be assumed that this increasing acceptance of lesbian and gay individuals would mimic the trajectory of public life and automatically extend to those with plurisexual sexualities and non-binary gender identities. It might also be expected that, given bisexual people comprise over 50 per cent of the LGB population (GLAAD, 2016), bisexual people of faith themselves would mobilise to ensure credence is given and rights are extended to this sizeable cohort. Yet this has not been the case. When the Archbishop of Canterbury, Justin Welby, spoke of the divisions in the Anglican Communion in January 2016 (Welby, 2016), in the run up to the Primates Meeting at Canterbury, these were in relation to "homosexuality" and "same-sex marriage". No mention was made of either bisexual or transgender Christians. This lack of acknowledgement, even if viewed as a problematic to be solved, is at the heart of the pain and anxiety felt by the majority of bisexual Christians I have interviewed in various research projects, from the west coast of America to the eastern outposts of Europe.

\section{Binary thought systems and bisexual Christian erasure}

Is it that bisexual people are not coming forward to tell their stories, as Pew (2013) suggests? Or is it that hierarchical systems and sexual identity politics require the existence of simplistic dichotomies (male/female, gay/ straight) to maintain existing power bases, effectively gagging bisexual and transgender "insurgents"? Thatcher (1993, p. 155) refers to the "over-used and over-tidy categories of heterosexual and homosexual".

At the root of bisexual stigmatisation within the church in the United Kingdom has been the somewhat notorious Issues in Human Sexuality (Church of England, 1991) a report conducted by the House of Bishops of the Church of England, the state church in the United Kingdom. Within a 43page generic document on human sexuality, just one paragraph was devoted to bisexuality, in which bisexual people of faith are basically instructed to exclusively engage in opposite-sex relationships if they cannot be celibate, and to seek counselling for a potential personality disorder. It would also appear to assume adultery as a matter of course on the part of the bisexual Christian. Not only is this deeply offensive to many bisexual Christians, particularly coming from the established Christian church of the United 
Kingdom; it also reveals an unambiguous ignorance of what bisexuality actually is. A generally accepted definition of bisexuality agreed by bisexual scholars and activists alike refers to an enduring attraction to people of more than one sex or gender (Alford-Harkey \& Haffner, 2014) - no more, no less.

In line with Fritz Klein's (1978) "non-existence myth", church leaders appear to be stymied by those outside of the sexuality binary, choosing to ignore bisexuality or demonise bisexual people over their apparent lack of moral integrity - what Kolodny (2000) refers to as the "weapon" used by heterosexual and homosexual people alike to deny bisexual Christians their full rights. In other words, the monosexual majority accuse bisexual people of promiscuity to underline their own moral superiority and exclude bisexual people.

The shadow of polyamory, which is often disproportionately associated with bisexuality, is used to suppress the bisexual voice - generally by those seeking affirmation of "permanent, faithful, stable" same-sex relationships to facilitate acceptance into worship communities. The so-called "slippery slope" argument (Klesse, 2018; Shepherd 2018) is frequently cited by church leaders as a reason to exclude bisexual people, on the basis that if bisexual Christians are allowed into church congregations, the institution of marriage will be under threat and thereby the very moral fabric of society will be challenged. That heterosexual people are only marginally less likely to engage in consensual non-monogamy than lesbian, gay, bisexual, or transgender individuals (Haupert et al., 2017) is ignored.

The sanctity of coupledom, a staple of church life, is threatened by nontraditional relationship configurations. The idolatry of the couple - what Wilkinson (2012) terms "compulsory coupledom" - which finds no clear and obvious role model in the central New Testament figures of Christ and Paul, and certainly not in the polygamous practices of the Old Testament, does further damage to those who do not fit easily into the "partner for life" paradigm.

Bisexual Christians may be further marginalised within these very relationships themselves, where a bisexual person in a different-sex relationship will be perceived to be straight, or homosexual, if in a same-sex relationship. Furthermore, some bisexual individuals will not challenge these assumptions, in order to ease their passage into a LGBT non-affirming environment, or to please an insecure partner who wishes to keep public knowledge of their mixed orientation relationship at bay (Shepherd, 2018; Toft, 2014). Both reduce visibility of bisexual people in church settings.

\section{Equal marriage as a negative impactor on bisexual rights}

One of the greatest ironies, as explored above, is the church's fascination with binary constructs, while simultaneously espousing a triune relationship 
of Father, Son, and Holy Spirit. This manifests itself in the preoccupation with coupledom in human relationships, the insistence on just two (hierarchically organised) relationship models (heterosexual or the less desirable homosexual variety) and gender binaries in liturgy, musical worship, and pastoral resources. This preoccupation then inadvertently leads to the concept known as bisexual erasure (Yoshino, 2000), where plurisexual identities are squeezed out of such classification systems.

Equal marriage has been viewed as a kind of nirvana for, and by, many Christian same-sex couples, desiring the blessing of their union in "God's house". Yet marriage equality has proved to be a double-edged sword for bisexual and transgender members of the LGBT faith community. The title of the 2012 book by openly homosexual UK priest Jeffrey John (2012), Permanent, Faithful, Stable: Christian Same-Sex Marriage, serves as an indicator of the platform upon which marriage equality has been achieved at least in the United Kingdom. Equal marriage has passed the morality test by focusing on monosexual, cisgendered lesbian and gay couples and the personal and sociological stability achieved through legalising same-sex marriage.

Yet, in the attempt to acquire the social capital of their heterosexual married counterparts, are not gay and lesbian individuals engaging in the same sexual politics seen in the West from the 1970s onwards? The Gay Liberation Movement saw the large bisexual and transgender component behind the Stonewall uprising sidelined, in the interests of promoting an innate sexuality argument in favour of monosexual orientations (Shepherd, 2017). Furthermore, the title of Jeffrey John's book suggests a desire to be accepted along the same lines as one's heterosexual counterparts - that is, as part of a monogamous partnership for life. Yet in so doing, the church whether intentionally or not - "others" all those who do not fit into this paradigm, unquestioningly asserting the superiority of monogamy over other family and relationship structures, however flawed the monogamous relationship may be.

My research into bisexual Christians in the United Kingdom and the United States (Shepherd 2017,2018) uncovered a malaise among clergy and scholars towards the middle-class aspirations of many same-sex couples. One ordained participant spoke of the "June and Ward Cleaver Syndrome" in relation to several gay couples he had married, referring to the American suburban sitcom that espouses middle-class moral values (Shepherd, 2017). Others, such as academic Lisa Diamond in an interview with myself in March 2016, have alluded to the smugness of those attaining middle-class heterosexual values; in becoming part of the established hierarchy, they forget and thereby "other" those still outside the mainstream culture (Shepherd, 2018). This is Duggan's (2002) concept of homonormativity that threatens those outside the gender and sexuality binary. Speaking of the Mormon Church, Diamond notes: 
religious communities just view bisexuality as a sort of different category. Like if you're bisexual, then you should do what we think God wants you to do. We're willing to give you a pass if you're exclusively gay, but if you're bisexual, then you really should get heterosexually married. And I think that puts a lot of faithful bisexuals in a really difficult position.

(Shepherd, 2018, p. 226)

Given the paucity of discourse on bisexuality in particular in the church, as revealed by my research (Shepherd 2017, 2018, in press), it would appear that marriage equality has done little to improve visibility or acceptance of bisexual Christians within church institutions, and has arguably served to - albeit by default - further entrench the stereotype of bisexual people as serial infidels, not as deserving of acceptance in the church as their more stable monosexual gay and lesbian counterparts. This has not been helped by the global shift towards right-wing politics in the United States, much of Eastern Europe and the post-Brexit United Kingdom.

\section{Sexual identity politics and horizontal oppression}

However, bisexual Christians find themselves dismissed by their LGBT peers as well as by church leaders. Bisexual Christians are often victims of the same historical sexual identity politics as secular bisexuals, deliberately sidelined to promote the innate sexuality arguments of their monosexual peers. This can be traced back to the late 1970s and early 1980s. While bisexual people played a prominent role in the gay liberation movements of the late 1960s and early 1970s, including the Stonewall Riots of 1969, their voices were suppressed a decade later in favour of championing gay and lesbian rights. This all but forced bisexual people to form their own bisexual organisations in the early 1980s (Zimmermann, 2000). However, this bisexual mobilisation did not extend to bisexual Christians, who have remained largely closeted.

It is perhaps obvious why homosexual Christians pursue monosexist discourses, for it strengthens the argument for the acceptance of gay and lesbian Christians by the church, if same-sex attraction is promoted as being genetic and immutable (Monro, 2015; Shepherd, 2018). Bisexual people, who may experience both same-sex and different-sex attractions, are clearly flies in the ointment of such arguments. Bisexuality suggests an element of "choice", so bisexual people must be silenced to propagate the innate sexuality argument and further the gay and lesbian cause. Reverend Neil Cazares-Thomas, British-born pastor of the LGBT-affirming Cathedral of Hope in Dallas, in critiquing horizontal oppression of bisexual congregants, describes how bisexual people are seen as the "Achilles heel" by lesbian and gay believers, "who fought to make a choice in their gender identity or sexual orientation or gender expression" (Shepherd, 2018, p. 227). Bisexual 
Christians "queer the notion of what it means to be lesbian or gay, and then they become seen as a traitor" (Shepherd, 2018, p. 227).

In an article notably titled "Reinforcing Binaries, Downgrading Passions: Bisexual Invisibility in Mainstream Queer Christian Theology", Bernhardt-House (2010, p. 55) describes queer theology as "inherently biased" against bisexual people. This bias is symptomatic of the malaise felt by queer theologians. Do they remain loyal to the social constructionist discourses of their predecessors or adopt a more essentialist view of human sexuality, which is a far better fit for the dualistic moral absolutes of the Christian faith, in terms of arguing the case for LGBT inclusion? All too often, the latter path is pursued in the name of political expediency, which is good news for monosexual lesbian and gay Christians, but not so much for the sexually fluid.

This emphasis on mononormativity (Ault, 1996) to the detriment of plurisexual individuals enables a gay-affirming case to be made for homosexuality in scripture. It can be argued that the Apostle Paul does not denounce homosexuality in his pastoral letters to the churches if we believe that homosexuality is fixed and therefore natural for that person. Rather, following this argument, Paul is referring to those who act against their inborn sexual nature, out of repression, under duress, or for various other reasons. He is not referring to those in committed same-sex relationships, but rather those who are performing acts that run contrary to their own natural sexual orientation. However, this resorting to simplistic binary categories of human sexuality - what liberation theologian Carter Heyward (1999, p. 117) terms "absolutisation" - excludes the bisexual Christian from a place at the table, and all too easily leads to horizontal oppression.

\section{The maintenance of heterosexual power bases}

This sidelining of bisexuality in queer theology in the name of sexual identity politics is reflected in church liturgies and pastoral resources, as touched on earlier by Garrigan (2009). It would perhaps be naïve to assume this is purely down to ignorance and unfamiliarity with bisexuality on the part of clergy, however. The maintenance of hierarchical power bases in the church clearly benefits those who benefit from such hegemonic systems namely, white male, reputedly heterosexual priests. And systems require clear-cut boundaries to operate effectively. There can be no place for those who do not fit neatly into preordained boxes, as Stuart and Thatcher (1997, p. 190) note:

bisexuals undermine the whole sexual system, the neat classification of people into homosexual and heterosexual, the pathologizing of homosexuality as a heterosexual disorder and so on. Bisexuality represents desire unfettered, and perhaps that is why those who experience are so studiously unacknowledged in church documents, and on 
the odd occasion where they are acknowledged, they are pathetically misrepresented as sexually indiscriminate and promiscuous.

Any mode of existence or relationship model that upsets the established order of heterosexual male supremacy must be kept at bay, with the biblical morality argument - usually based on nebulous translations of scripture - used to suppress all those who do fit into neat monosexual, cisgender categories. This moralism is described by Heyward (1999, p. 17) as "an ideology of rightness and a posturing of certitude that absolutizes ideas and abstractions rather than actual relationships that are loving and just". Such moralism is inflexible and cannot accept human realities, being by nature "unchanging, unbending and therefore not open to honest questioning, even by conscientious, responsible people" (Heyward, 1999, p. 19).

It is perhaps unsurprising, therefore, that bisexuality remains taboo in faith circles, when both queer theologians and church leaders would appear to be disinclined to acknowledge sexual and gender fluidity. Thus, the bisexual Christian is silenced by both the homosexual Christian seeking to make a case for their inborn sexual orientation, and the dominant heterosexual church leadership, determined to maintain the status quo to protect privileged positions. The grudging acceptance of same-sex marriage has also added to this silencing of the bisexual voice, as leading sexualities academic Lisa Diamond explained in an interview with me in March 2016:

A lot of studies have found that bisexual individuals actually have far higher rates of anxiety and depression than exclusively gay individuals and the prevailing thinking is that it's because their needs are adequately addressed by a discourse that goes, 'Oh, you poor gay people, we'll let you have your same sex relationships because you can't possibly do anything else'. Bisexual individuals are not sort of served by that discourse, yet they're not getting any more acceptance from the heterosexual side. So, they end up getting a sort of double dose of marginalisation.

(Shepherd, 2018, p. 86)

The silence on bisexuality can be explained further by the Christian church's "erotophobia" (Goss, 2004) or traditionally sex-negative position. In an interview with me in May 2016, bisexual activist Robyn Ochs spoke of the "very profound anti-sex beliefs" and "sex negativity" she had witnessed within religious institutions (Shepherd, 2018). It has been abundantly clear from my interviews with bisexual Christians around Europe (Shepherd, in press), that not only is LGBT barely spoken about, but the word "sex" itself is rarely uttered. Since the word "bisexuality" contains "sex" in its root in a way that the "cuddlier" or more user-friendly terms "gay" and "lesbian" do not, both in English and other European languages, it was felt that this rendered discussion of bisexuality particularly challenging (Shepherd, 2017). In conservative church cultures specifically, where dualistic notions 
of sinful, sexual bodies waging war against our spiritual nature are peddled, it is clear to see why dialogue on sexuality per se, let alone sexual fluidity, is considered taboo.

\section{Bisexual Christians in Europe}

My current qualitative research on the situation of bisexual Christians in Europe, though still in its infancy, is also providing data symptomatic of a cohort routinely ignored or stigmatised by the mainstream Christian church. This is the case even within those nations considered advanced in the area of LGBT rights, such as Malta, last year's most LGBT-friendly nation according to the ILGA Rainbow Map of Europe (ILGA Europe, 2019). As one male Maltese participant commented: "There's very little talk about it, about bisexuality. When it comes to gay and lesbian and even trans, now it's growing. But with bisexuality, it is totally, totally missing" (Shepherd, in press).

This silence is not restricted to Catholic countries. Another participant from largely Protestant Sweden stated that, "The Church of Sweden representatives exclude all but the homosexuals (and possibly the poor, poor trans people) and then beam proudly for being so broad-minded" (Shepherd, in press).

This silence would appear to have its roots in shame. As a 21-year-old female participant from the Netherlands noted:

We're not that topical, being bisexual and Christian ... I have a feeling that we're still being oppressed and we're being very invisible. People don't talk about that openly, because there is a lot of shame, especially around being bisexual ... because we have the status of being freaky.

(Shepherd, in press)

Her experiences were mirrored throughout the Netherlands in findings by Dutch journalist Hester Nagelhout, who recently investigated the attitudes of churches towards bisexuality in her homeland and has agreed to share her research findings. As one of Nagelhout's bisexual Christian women commented (translated from Dutch): "Most women are scared of the prejudices around it. That it's just a phase or that they want it both ways" (Nagelhout, 2018).

Nagelhout also interviewed members of the priesthood, with one stating, "I have only encountered it (bisexuality) once or twice in 40 years as a minister". This seems astounding, given that bisexual people comprise 52 per cent of the LGB population (GLAAD, 2016) and given the relative liberalism of Dutch society compared with many of its European neighbours - the Netherlands occupies 12th spot out of 49 European countries in the most recent ILGA Rainbow Map of Europe (ILGA Europe, 2019). However, as Dutch bisexual scholars note, the Netherlands has a long history of ignoring bisexuality as a valid sexual identity, let alone as part of a bisexual Christian intersectional identity. Van Alphen traces the invisibility of bisexuality in 


\section{Carol A. Shepherd}

the Dutch homosexual movement from 1946-72 (Van Alphen, 2017), while Maliepaard (2015) notes that subsequent discussions on sexual citizenship in the Netherlands have focused exclusively on heterosexual and homosexual people.

This silence is clearly not restricted to the Netherlands. When I put out a social media call for church youth resources in September 2019, a contact in Finland responded, "In Finland, we have a long tradition of not mentioning (LGBT) ... you will get a good idea of that by looking at this latest confirmation plan". I entered "sexual orientation" into the attached confirmation booklet for young people of the Evangelical Lutheran Church of Finland and got no results. Regarding sexuality, I found the generic advice below, which can neither be interpreted as affirming nor non-affirming:

A key area of growth for a young person is coming to understand their own sexuality, which tends to come to light in the everyday life of their confirmation work. Sexuality is a natural life force, created as an intrinsic part of people of all ages. A mature and healthy sexuality is to love and accept people as individuals, one's own gender and body, and those of others.

(Evangelical Lutheran Church of Finland, 2017, p. 40)

In one sense, such a passage does at least offer an embodied understanding of human sexuality. Yet it remains vague on the issue of sexual orientation.

The acceptance of plurisexuality among young people indicated by the opening statistics has not spread to Eastern Europe yet. A participant from Poland commented:

Although I am a very self-confident person ... I sometimes feel quite shy about saying opening that I'm non-straight ... the people I work with are young, open-minded, etc. but still I'm afraid they would look at me not as a person, but through their prejudice.

(Shepherd, in press)

While is not surprising that acceptance of LGBT identities is patchy in Eastern Europe, where homosexuality has been alternately outlawed by communism and now by the far right - such as Poland's ruling Law and Justice Party - the erasure of bisexuality in the more liberal Northern and Western European countries of Europe from data collected so far suggests that my existing empirical research findings from the United Kingdom and the United States (Shepherd 2017, 2018) will be mirrored in this European study.

\section{Conclusion}

In this chapter, I have explored the key reasons why bisexuality remains taboo as a topic for discussion in the mainstream Christian denominations. 
A combination of hierarchical church leadership structures, horizontal oppression, ignorance of bisexuality and general erotophobia creates a toxic cocktail of denial, which serves to dismiss the bisexual experience and, with it, the wellbeing of these individuals. For vulnerable young people, this silence may have a severely detrimental effect on their mental and physical wellbeing (Shepherd, 2018).

The issues faced by bisexual Christians investigated in existing research projects (Shepherd, 2018; Toft 2012) are mirrored in my current research into bisexuality in Europe, where the silence on bisexuality is even more deafening. Even those countries traditionally deemed liberal in terms of acceptance of LGBT people, such as Belgium and Sweden, remain curiously silent on the subject of bisexuality. Malta, which tops the current ILGA league of LGBT-affirming nations in Europe (ILGA Europe, 2019), remains steadfastly silent on the topic. This is both puzzling and troubling in equal measure, not least in terms of the implications for the mental health and spirituality of young people.

However, what has become apparent both from my research and in my capacity as a bisexual Christian activist is just how few people there are with this specific intersectional identity who are willing to publicly challenge essentialist and monosexist discourses on human sexuality in the church. In my interviews with participants, both in my homeland and around Europe, I have not uncovered a single bisexual Christian support group, nor indeed a fellow activist willing to set one up. I have found just a handful of individuals willing to speak in public about being bisexual and Christian across Europe.

From my own empirical research in the United Kingdom, the United States, and Europe, it would seem imperative that further studies are undertaken on the mental health implications of ignoring bisexuality as a valid sexual orientation within the church. Closely linked to this, further research should be done on binary understandings of sex, gender, and sexuality, with a view to making recommendations on bi-inclusivity in church communities, in order to enable those with plurisexual identities to access worship and fellowship in the Christian church.

From an activist perspective, bisexual Christians themselves need to speak up and mobilise at a national level and beyond, perhaps initially forming a European support organisation online. The welfare implications of dismissing sexuality-related issues, both within secular and religious communities, must be addressed by clergy and health practitioners, if the sort of personal tragedies affecting bisexual people that we read of daily in publications such as Pink News - and which my own empirical research has uncovered - are to be avoided.

\section{References}

Alford-Harkey, M., \& Haffner, D.W. (2014). Bisexuality: Making the invisible visible in faith communities. Westport, CT: The Religious Institute. 
Ault, A. (1996). Ambiguous identity in an unambiguous sex/gender structure: The case of bisexual women. The Sociological Quarterly, 37(3), 449-63. doi: 10.1111/ j.1533-8525.1996.tb00748.x

Bernhardt-House, P.A. (2010). Reinforcing binaries, downgrading passions: Bisexual invisibility in mainstream queer Christian theology. Journal of Bisexuality, 10(12), 54-63. doi: 10.1080/15299711003609658

Bullivant, S. (2018). Europe's young adults and religion: Findings from the European social survey (2014-16) to inform the 2018 Synod of Bishops. Retrieved from www.stmarys.ac.uk/research/centres/benedict-xvi/docs/2018-mar-europe-youngpeople-report-eng.pdf

Church of England. (1991). Issues in human sexuality. London: Church House.

Ditch the Label. (2017). The annual bullying survey 2017. Retrieved from www. ditchthelabel.org/research-papers/the-annual-bullying-survey-2017/

Duggan, L. (2002). The new homonormativity: The sexual politics of neoliberalism. In R. Castronova \& D. Nelson (Eds.), Materializing democracy: Toward a revitalized cultural politics (pp. 175-94). Durham, NC: Duke University Press.

European Union. (2019). Marriage. Retrieved from https://europa.eu/youreurope/ citizens/family/couple/marriage/index_en.htm

Evangelical Lutheran Church of Finland. (2017). A great miracle: Confirmation preparation plan. Retrieved from https://evl.fi/documents/1327140/39461555/ A+Great+Miracle+-+Confirmation+Plan+2017/9e00b32d-6b14-b0a7-066714 b6eba60d59

Garrigan, S. (2009). Queer workshop. Theology \& Sexuality, 15(2), 211-30. doi: $10.1558 /$ tse.v15i2.211

GLAAD. (2016). Reporting on the bisexual community: A resource for journalists and media professionals. Retrieved from www.glaad.org/sites/default/files/ BiMediaResourceGuide.pdf

Goss, R.E. (2004). Proleptic sexual love: God's promiscuity reflected in Christian polyamory. Theology \& Sexuality, 11(1), 52-63. doi: 10.1177/135583580401100105

Haupert, M.L., Gesselman, A.N., Moors, A.C., Fisher, H.E., \& Garcia, J.R. (2017). Prevalence of experiences with consensual nonmonogamous relationships: Findings from two national samples of single Americans. Journal of Sex \& Marital Therapy, 43(5), 424-40. doi: 10.1080/0092623X.2018.1462277

Heyward, C. (1999). Saving Jesus from those who are right: Rethinking what it means to be Christian. Minneapolis, MN: Fortress Press.

Hutchins, L., \& Williams, H.S. (2018). Sexuality, religion and the sacred: Bisexual, pansexual and polysexual perspectives. London: Routledge.

ILGA Europe. (2019). Rainbow Europe. Retrieved from www.rainbow-europe.org/ country-ranking

John, J. (2012). Permanent, faithful, stable: Christian same-sex marriage. London: Darton, Longman \& Todd.

Klein, F. (1978). The bisexual option: A concept of one bundred percent intimacy. New York: Arbor House.

Klesse, C. (2018). Bisexuality, slippery slopes, and multipartner marriage. Journal of Bisexuality, 18(1), 35-53. doi: 10.1080/15299716.2017.1373264

Kolodny, D. (2000). Blessed bi spirit: Bisexual people of faith. London: Bloomsbury. Levy, D.L., \& Harr, J. (2018). "I never felt like there was a place for me": Experiences of bisexual and pansexual individuals with a Christian upbringing. Journal of Bisexuality, 18(2), 186-205. doi: 10.1080/15299716.2018.1431169 
Lingwood, S. (2010). Bi Christian Unitarian: A theology of transgression. Journal of Bisexuality, 10(1-2), 31-43. doi: 10.1080/15299711003609625

Maliepaard, E. (2015). Bisexual citizenship in the Netherlands: On homoemancipation and bisexual representations in national emancipation policies. Sexualities, 18(4), 377-93. doi: 10.1177/1363460714550906

Monro, S. (2015). Bisexuality: Identities, politics, and theories. London: Palgrave Macmillan. doi:10.1057/9781137007315

Nagelhout, H. (2018). De zichtbaarheid van biseksuele christenen in Nederland: Hoe zichtbaar zijn biseksuele christenen in Nederland?' [The visibility of bisexual Christians in the Netherlands: How visible are bisexual Christians in the Netherlands?]. Bachelor's thesis, School voor de Journalistiek, Utrecht, Netherlands.

Out Now (2015). LGBT diversity: Show me the business case. Retrieved from www. outnowconsulting.com/media/24545/Report-SMTBC-2015-V30sm.pdf

Pew Research Center (2013). US Religious Landscape Survey. Retrieved from http:// religions.pewforum.org

Robinson, M. (2015). Bisexual people. In A. Thatcher (Ed.), The Oxford handbook of theology, sexuality, and gender (pp. 640-56). Oxford: Oxford University Press.

Shepherd, C.A. (2017). Bisexual Christians \& mental health: Why the church needs to be more welcoming. PhD thesis. University of Winchester.

Shepherd, C.A. (2018). Bisexuality and the Western Christian Church: The damage of silence. London: Palgrave Macmillan.

Shepherd, C.A. (2020). Depression and suicidality among bisexual Christians. In A.K.T. Yip \& A. Toft (Eds.), Bisexuality, religion and spirituality: Critical perspectives (pp. 156-75). London: Routledge.

Shepherd, C.A. (in press). Bi: The way. Pastoring bisexual Christians in Europe. Eastleigh: Easy Yoke Publishing under Shepherd (in press).

Sommers, J. (2016). 119: My life as a bisexual Christian. London: Darton, Longman $\&$ Todd.

Stuart, E., \& Thatcher, A. (1997). People of passion: What the churches teach about sex. London: Burns \& Oates.

Thatcher, A. (1993). Liberating sex: A Christian sexual theology. London: SPCK.

The Williams Institute. (2018). Acceptance of LGBT people and rights has increased around the world. Retrieved from https://williamsinstitute.law.ucla.edu/press/ press-releases/lgbt-acceptance-increases-press-release

Toft, A. (2012). Bisexuality and Christianity: Negotiating disparate identities in church life. In A.K.T. Yip (Ed.), The Ashgate research companion to contemporary religion and sexuality (pp.189-203). London: Routledge.

Toft, A. (2014). Re-imagining bisexuality and Christianity: The negotiation of Christianity in the lives of bisexual women and men. Sexualities, 17(5-6), 54664. doi: $10.1177 / 1363460714526128$

Van Alphen, E.C.J. (2017). Erasing bisexual identity: The visibility and invisibility of bisexuality as a sexual identity in the Dutch homosexual movement, 1946-1972. Journal of Homosexuality, 64(2), 273-88. doi: 10.1080/00918369.2016.1179032

Welby, J. (2016). Communiqué from the Primates' Meeting 2016. Retrieved from www.anglicannews.org/features/2016/01/communique-from-the-primatesmeeting-2016.aspx

Wilkinson E. (2012). The romantic imaginary: Compulsory coupledom and single existence. In S. Hines, \& Y. Taylor (Eds.), Sexualities: Past reflections, future directions (pp. 130-45). London: Palgrave Macmillan. 


\section{Carol A. Shepherd}

Yip, A.K.T. (2003). Sexuality and the church. Sexualities, 6(1), 60-64. doi: 10.1177/ 1363460703006001007

Yip, A.K.T., \& Toft, A. (2020). Bisexuality, religion and spirituality: Critical perspectives. London: Routledge.

Yoshino, K. (2000). The epistemic contract of bisexual erasure. Stanford Law Review, 52(2), 353-461. doi: 10.2307/1229482

YouGov. (2015). One in two young people say they are not $100 \%$ heterosexual. Retrieved from https:/yougov.co.uk/topics/lifestyle/articles-reports/2015/08/16/ half-young-not-heterosexual

Zimmerman, B. (2000). Lesbian histories and cultures: An Encyclopaedia, Vol. 1. London: Routledge. 